\title{
PENGGUNAAN DAUN SALAM TERHADAP KLIEN ASAM URAT UNTUK MENURUNKAN KADAR ASAM URAT DI KELURAHAN GUNUNG AGUNG
}

\author{
M. Arifki Zainaro ${ }^{1}$, Dita Resi Andrianti ${ }^{2}$, Teguh Pribadi ${ }^{3}$, Djunizar \\ Djamaludin $^{4}$, Andoko ${ }^{5}$, M. Ricko Gunawan ${ }^{6}$, Rika Yulendasari ${ }^{7}$ \\ 1,3,4,5,6,7 Dosen Keperawatan Universitas Malahayati \\ ${ }^{2}$ Mahasiswa Program Studi Ilmu Keperawatan Universitas Malahayati \\ Email: m.arifkiz@yahoo.com; ditaresiandriantu@gmai.com
}

\begin{abstract}
ABSTRAK
Artritis gout (asam urat) adalah penyakit yang timbul akibat kadar asam urat darah yang berlebihan, yang menyebabkan kadar asam urat darah berlebihan adalah produksi asam urat di dalam tubuh lebih banyak dari pembuangannya, selain itu penyebab produksi asam urat di dalam tubuh berlebihan dapat terjadi karena faktor genetik (bawaan), faktor makanan dan faktor penyakit. Pengobatan tradisional untuk asam urat yaitu rebusan daun salam. Tujuan setelah penyuluhan dan demonstrasi, diharapkan pemberian daun salam pada klien asam urat untuk menurunkan kadar asam urat. Adapun kegiatan yang dilakukan berupa penyuluhan menggunakan leaflet dan demonstrasi pembuatan daun salam. Terdapat penurunan kadar asam urat setelah meminum air rebusan daun salam pada penderita asam urat di Kelurahan Gunung Agung. Dengan demikian, pemberian rebusan daun salam sangat efektif dalam menurunkan kadar asam urat.
\end{abstract}

Kata Kunci: Daun Salam, Asam urat, Kadar Asam urat

\begin{abstract}
Gouty arthritis (gout) is a disease caused by excessive blood uric acid levels, which causes excessive blood uric acid levels is the production of uric acid in the body more than its disposal, other than that the cause of excessive uric acid production in the body can occur because genetic factors (hereditary), dietary factors and disease factors. Traditional treatment for gout is salam leaf decoction. The purpose after counseling and demonstration, is expected to give salam leaves to the uric acid's client to reduce uric acid levels. The activities carried out in the form of counseling using leaflets and demonstrations making salam leaves. There is a decrease in uric acid levels after drinking of salam leaves stew in patients with gout at Gunung Agung Village. Thus, giving salam leaf stew is very effective in reducing uric acid levels.
\end{abstract}

Keywords: Salam leaves, gout, uric acid levels 


\section{PENDAHULUAN}

Sehat adalah keadaan sejahtera secara fisik, mental dan sosial yang merupakan satu kesatuan, bukan hanya terbebas dari penyakit maupun cacat. Sehat adalah keadaan sejahtera dari badan, jiwa, dan sosial sehingga memungkinkan setiap orang dapat hidup produktif secara sosial dan ekonomi. Hal ini berarti kesehatan seseorang berperan panting untuk menunjang produktifitas orang tersebut dalam hidupnya (Hasrul, \& Rini, 2017).

Di dunia pravelensi penyakit gout arthritis terjadi sebanyak 34,2\% (World Health Organization, 2017). Gout arthritis sering terjadi di negara maju seperti Amerika. Prevalensi gout arthritis di Negara Amerika sebesar 26,3\% dari total penduduk. Peningkatan kejadian gout arthritis tidak hanya terjadi di negara maju saja. Namun, peningkatan juga terjadi di negara berkembang, salah satunya di Negara Indonesia (Kumar \& Lenert, 2016; Eni, Ari \& Riri, 2018). Prevalensi gout arthritis di Indonesia semakin mengalami peningkatan. Pada tahun 2013 kejadian gout arthritis sebesar 11,9\% (Kementerian Kesehatan Republik Indonesia, 2018).

Artritis gout (asam urat) adalah penyakit yang timbul akibat kadar asam urat darah yang berlebihan, yang menyebabkan kadar asam urat darah berlebihan adalah produksi asam urat di dalam tubuh lebih banyak dari pembuangannya, selain itu penyebab produksi asam urat di dalam tubuh berlebihan dapat terjadi karena faktor genetik (bawaan), faktor makanan dan faktor penyakit misalnya kanker darah (Kertia, 2009). Artritis gout lebih banyak dijumpai pada laki-laki dibandingkan perempuan. Prevalensi gout tertinggi pada kalangan lanjut usia dikaitkan dengan insufisiensi renal atau gangguan metabolisme purin. Gejala yang khas pada artritis gout adalah adanya keluhan nyeri, bengkak, dan terdapat tanda-tanda inflamasi pada sendi metatarsal-phalangeal ibu jari kaki (atau yang disebut dengan podagra). Estimasi prevalensi menyatakan bahwa sebesar 8,5\% artritis gout terjadi pada perempuan dan 6,1\% terjadi pada laki-laki (Kementerian Kesehatan Republik Indonesia, 2018).

Berdasarkan onsetnya, artritis gout dibagi menjadi dua, yaitu episode akut dan kronik. Artritis gout fase akut menyebabkan morbiditas yang tinggi, namun apabila diterapi segera setelah munculnya gejala dapat menghasilkan prognosis yang baik. Pada fase kronik, gout dapat menyebabkan destruksi sendi yang berat dan gangguan ginjal (Wiraputra, 2017). Rasa sakit akibat asam urat dapat terjadi pada malam dan pagi hari saat bangun tidur dan bisa berlangsung selama 4-11 hari. (Utomo, 2014; Setianingrum, Istika \& Dwi, 2019). Penanganan yang dilakukan untuk mencegah terjadinya peningkatan kadar asam urat dalam darah, antara lain pengaturan diet, menghindari makanan tinggi purin, konsumsi vitamin dan mineral yang cukup, olahraga rutin, berhenti merokok, pengendalian stres dan dapat diberikan obatobatan untuk terapi farmakologi. Pengobatan lain yang dapat digunakan untuk mengatasi peningkatan kadar asam urat yaitu dengan pengobatan herbal (Sari, \& Syamsiyah, 2017). Pengobatan tradisional sekarang ini sudah menjadi alternatif lain dari pengobatan modern. Keuntungan dari penggunaan obat tradisional adalah efek samping yang relatif kecil dibandingkan dengan obat yang modern dan pengolahan pada obat tradisional juga sangat sederhana dan dapat digunakan secara turunmenurun.

Tumbuhan obat yang dapat digunakan sebagai anti hiperurisemia untuk menurunkan kadar asam urat adalah tanaman salam (Syzygium polyanthum 
Wight). Bagian tanaman yang dapat digunakan adalah daun yang masih segar atau yang sudah dikeringkan. Tanaman salam mengandung senyawa kimia seperti tanin, flavonoid, alkaloid, dan minyak atsiri yang terdiri dari sitrat dan eugenol. Daun salam mampu memperbanyak produksi urin (diuretik) sehingga dapat menurunkan kadar asam urat darah (Ningtiyas, \& Ricky, 2016; Setianingrum, Istika \& Dwi, 2019). Hasil penelitian ini sesuai dengan penelitian sebelumnya di Padang yang menunjukkan pengaruh pemberian rebusan daun salam terhadap penurunan kadar asam urat dengan uji paired sample t test yang menunjukkan adanya pengaruh pemberian rebusan daun salam terhadap penurunan kadar asam urat pada penderita gout artritis dengan tingkat kemaknaan $95 \%$ dan didapatkan nilai $\rho$-value 0,000 lebih kecil dari nilai signifikan 0,05 $(0,00<0,05)$ (Febriyanti, \& Mira, 2018).

Berdasarkan latar belakang tersebut, penulis tertarik untuk melakukan studi kasus "asuhan keperawatan komprehensif menggunakan daun salam terhadap klien asam urat untuk menurunkan kadar asam urat di kota bandar lampung tahun 2020".

\section{MASALAH}

Alasan saya memilih tempat penyuluhan kesehatan tentang asam urat dan demontrasi tentang pemberian air rebusan daun salam di Kelurahan Gunung Agung ialah karena keluarga saya sendiri memiliki masalah kesehatan asam urat yang tinggi, dimana tujuan umum dalam kegiatan ini diharapkan pemberian air rebusan daun salam dapat menurunkan kadar asam urat pada klien dengan asam urat, dan tujuan khusus dalam kegiatan yaitu asuhan keperawatan, telaah jurnal untuk menentukan intervensi, evaluasi hasil aplikasi intervensi, perbandingan hasil intervensi pemberian air rebusan daun salam.

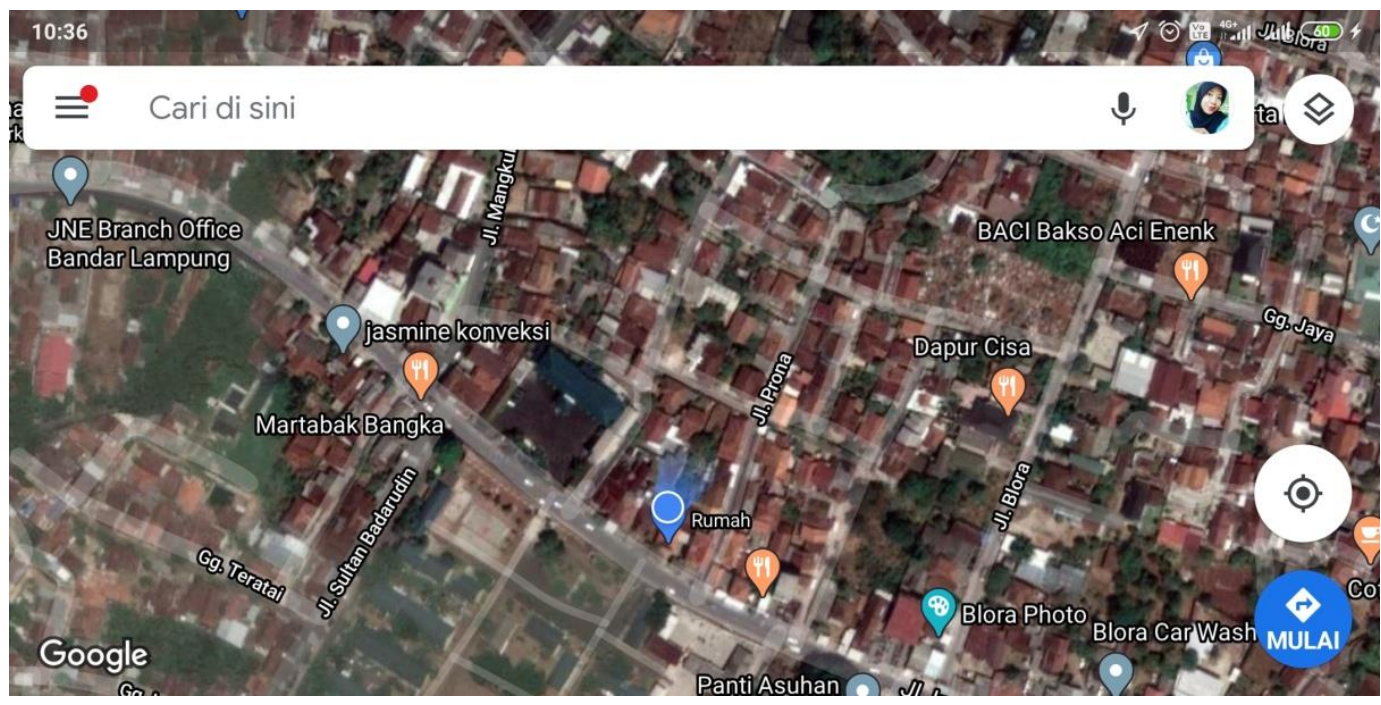

Gambar 2.1 Lokasi penyuluhan dan demonstrasi 


\section{METODE}

1. Tujuan Persiapan

Tahap persiapan dari kegiatan adalah pembuatan pre planning, persiapan penyajian leaflet dan demonstrasi, tempat dan alat-alat lainnya disiapkan oleh peneliti. Pembuatan leaflet dibuat pada hari senin 27 april 2020, pada tanggal 05 mei 2020 dilakukan penyuluhan, pengecekan asam urat, dan demonstrasi pembuatan air rebusan daun salam.

\section{Tahap Pelaksanaan}

Kegiatan ini dengan pemberitahuan kepada klien, dan dilanjutkan penyuluuhan, pengecekan asam urat, dan demonstrasi pembuatan air rebusan daun salam.

3. Evaluasi

a. Struktur

Peserta hadir 3 orang yaitu perempuan. Setting tempat sudah sesuai dengan rencana dan perlengkapan yang dilakukan untuk penyuluhan sudah tersedia dan sudah digunakan sebagaimana mestinya. Peran peneliti sebagai moderator, notulen, observer, dan juga fasilitator. Penggunaan bahasa yang dipraktekkan sudah komunikatif dalam penyampaian, klien dapat memahami dan dapat mempraktekkan kembali yang di demonstrasikan.

b. Proses

Pelaksanaan kegiatan dilaksanakan pukul 10.00 s/d 10.30 WIB. Sesuai dengan jadwal yang sudah ditentukan.

c. Hasil

1. Klien dapat memahami dan mengerti tentang pengertian terapi air rebusan daun salam.

2. Klien dapat memahami dan mengerti tentang tujuan dilakukannya terapi air rebusan daun salam.

3. Klien dapat memahami dan mengerti tentang manfaat dan teknik pembuatan air rebusan daun salam.

4. Klien dapat memahami dan mengerti tentang langkah-langkah pembuatan air rebusan daun salam.

\section{HASIL DAN PEMBAHASAN}

Metode pelaksanaan pemberian terapi air rebusan daun salam dilaksanakan pada tanggal 05 Mei 2020 s/d 11 Mei 2020. Penelitian dilakukan selama 7 hari, setelah dilakukan pemberian terapi selama 7 hari didapatkan kadar asam urat klien menurun. Berikut pelaksanaan penyuluhan, pengecekan kadar asam urat dan pemberian terapi air rebusan daun salam:
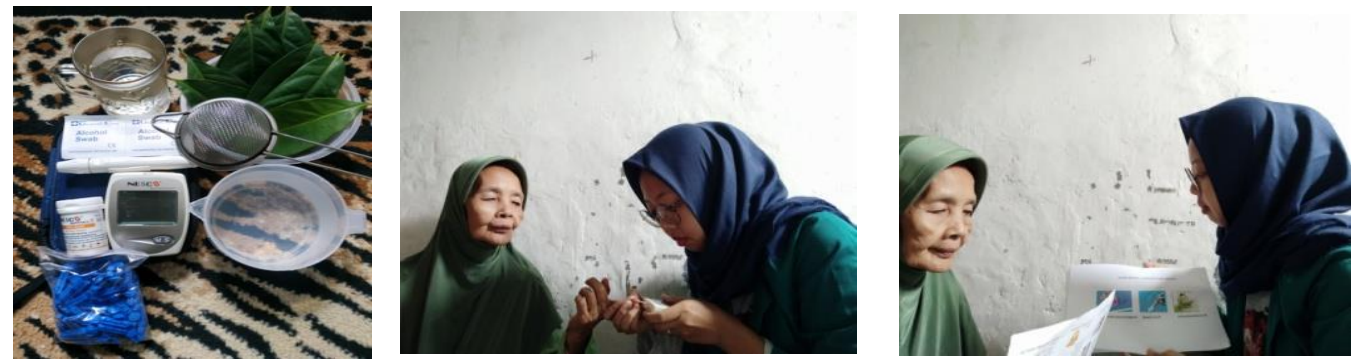

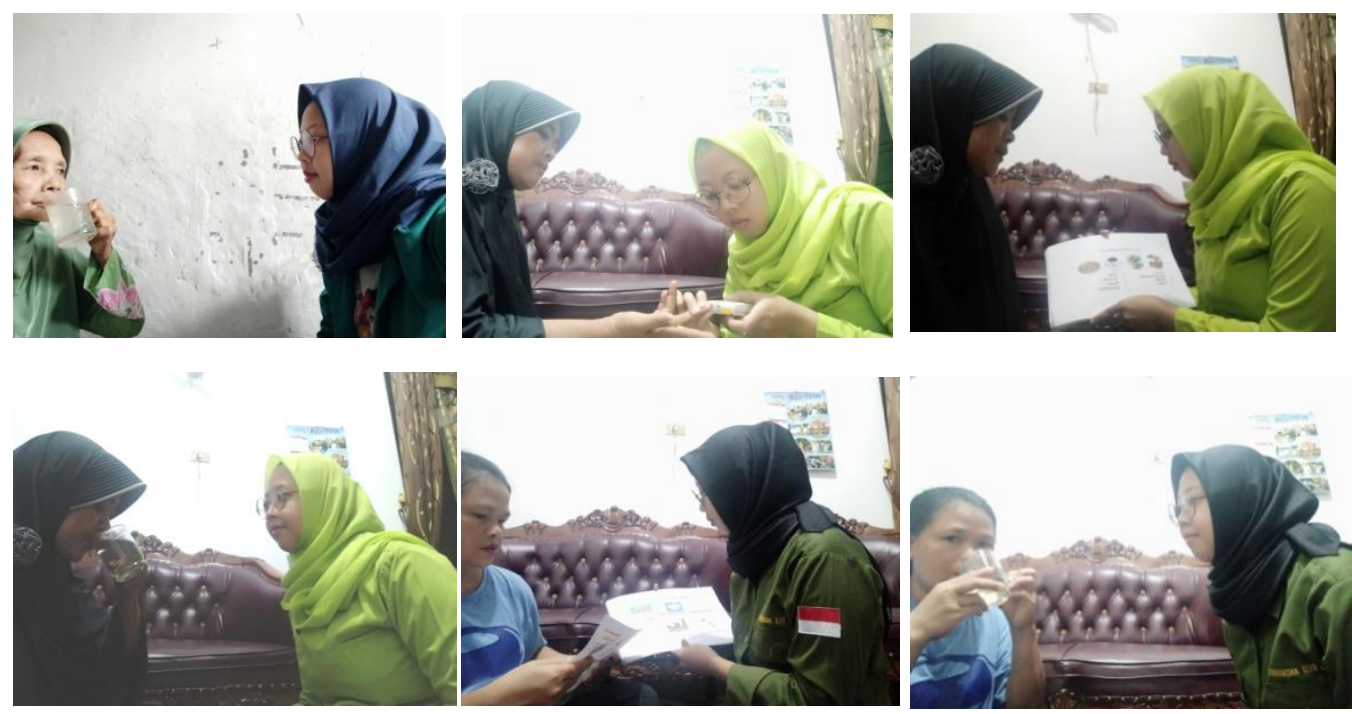

Gambar 4.1 pelaksanaan penyuluhan, pengecekan kadar asam urat, dan pemberian terapi air rebusan daun salam

1. Hasil

Tabel 4.1 Evaluasi Kadar Asam Urat

\begin{tabular}{|c|c|c|c|c|c|c|c|c|c|}
\hline \multirow{3}{*}{ No. } & \multirow{3}{*}{$\begin{array}{c}\text { Nama } \\
\text { Klien } \\
\text { (Inisial) }\end{array}$} & \multicolumn{8}{|c|}{ Kadar Asam Urat } \\
\hline & & \multirow{2}{*}{$\begin{array}{c}\text { Sebelum } \\
\text { diberikan } \\
\text { terapi }\end{array}$} & \multicolumn{7}{|c|}{ Sesudah diberikan terapi } \\
\hline & & & 1 & 2 & 3 & 4 & 5 & 6 & 7 \\
\hline 1. & Ny. S & $6,5 \mathrm{mg} / \mathrm{dl}$ & $\begin{array}{c}6,5 \\
\mathrm{mg} / \mathrm{dl}\end{array}$ & $\begin{array}{c}6,2 \\
\mathrm{mg} / \mathrm{dl}\end{array}$ & $\begin{array}{c}6,0 \\
\mathrm{mg} / \mathrm{dl}\end{array}$ & $\begin{array}{c}5,9 \\
\mathrm{mg} / \mathrm{dl}\end{array}$ & $\begin{array}{c}5,5 \\
\mathrm{mg} / \mathrm{dl}\end{array}$ & $\begin{array}{c}5,3 \\
\mathrm{mg} / \mathrm{dl}\end{array}$ & $\begin{array}{c}5,3 \\
\mathrm{mg} / \mathrm{dl}\end{array}$ \\
\hline 2. & Ny. S & 7 mg/dl & $\begin{array}{c}7 \\
\mathrm{mg} / \mathrm{dl}\end{array}$ & $\begin{array}{c}6,9 \\
\mathrm{mg} / \mathrm{dl}\end{array}$ & $\begin{array}{c}6,7 \\
\mathrm{mg} / \mathrm{dl}\end{array}$ & $\begin{array}{c}6,4 \\
\mathrm{mg} / \mathrm{dl}\end{array}$ & $\begin{array}{c}6,0 \\
\mathrm{mg} / \mathrm{dl}\end{array}$ & $\begin{array}{c}5,7 \\
\mathrm{mg} / \mathrm{dl}\end{array}$ & $\begin{array}{c}5,2 \\
\mathrm{mg} / \mathrm{dl}\end{array}$ \\
\hline 3. & Ny. L & $6,8 \mathrm{mg} / \mathrm{dl}$ & $\begin{array}{c}6,8 \\
\mathrm{mg} / \mathrm{dl}\end{array}$ & $\begin{array}{c}6,6 \\
\mathrm{mg} / \mathrm{dl}\end{array}$ & $\begin{array}{c}6,3 \\
\mathrm{mg} / \mathrm{dl}\end{array}$ & $\begin{array}{c}6,3 \\
\mathrm{mg} / \mathrm{dl}\end{array}$ & $\begin{array}{c}5,8 \\
\mathrm{mg} / \mathrm{dl}\end{array}$ & $\begin{array}{c}5,5 \\
\mathrm{mg} / \mathrm{dl}\end{array}$ & $\begin{array}{c}5,0 \\
\mathrm{mg} / \mathrm{dl}\end{array}$ \\
\hline
\end{tabular}

2. Pembahasan

Pada tabel 4.1 dapat dilihat evaluasi hari terakhir pemeriksaan kadar asam urat terjadi penurunan antara klien $1 \mathrm{Ny}$. S, klien $2 \mathrm{Ny}$. S dan klien 3 Ny. L, diperoleh data pada klien $1 \mathrm{Ny}$. S kadar asam urat sebelum diberikan asuhan keperawatan yaitu kadar asam urat: $6,5 \mathrm{mg} / \mathrm{dl}$. Pada klien 2 Ny. $\mathrm{S}$ kadar asam urat sebelum diberikan asuhan keperawatan yaitu kadar asam urat: $7 \mathrm{mg} / \mathrm{dl}$, sedangkan pada klien $3 \mathrm{Ny}$. L kadar asam urat sebelum diberikan asuhan keperawatan yaitu kadar asam urat: 6,8 $\mathrm{mg} / \mathrm{dl}$. Hasil penelitian ini sesuai dengan penelitian sebelumnya yang dilakukan oleh Febriyanti, \& Mira (2018) tentang pengaruh pemberian rebusan daun salam (syzygium polyanthum) terhadap kadar asam urat pada lansia juga didapatkan kadar asam urat sebelum diberikan intervensi yaitu $8,14 \mathrm{mg} / \mathrm{dl}$, dimana terdapat kadar asam urat yang tinggi, yang disebabkan karena bertambahnya usia. Asam urat adalah suatu penyakit karena kelainan metabolisme purin (Hiperurisemia). Pada keadaan ini bisa terjadi oversekresi asam urat, atau penurunan fungsi 
ginjal yang mengakibatkan penurunan ekresi asam urat atau kombinasi keduanya. Kadar asam urat normal pada wanita yaitu 2,6 - $6 \mathrm{mg} / \mathrm{dL}$ dan pada pria yaitu 3 - 7 mg/dL ( Andriani, 2016; Roza, \& Putri, 2016).

Pada klien $1 \mathrm{Ny}$. S setelah diberikan intervensi rebusan daun salam selama kurun waktu 7 (tujuh) hari, dari hasil pemeriksaan didapatkan kadar asam urat pada hari ke 1 (pertama): $6,5 \mathrm{mg} / \mathrm{dl}$, pada hari ke 2 (dua): $6,2 \mathrm{mg} / \mathrm{dl}$, pada hari ke 3 (tiga): $6,0 \mathrm{mg} / \mathrm{dl}$, pada hari ke 4 (empat): $5,9 \mathrm{mg} / \mathrm{dl}$, pada hari ke 5 (lima): $5,5 \mathrm{mg} / \mathrm{dl}$, pada hari ke 6 (enam): 5,3 mg/dl, dan pada hari ke 7 (tujuh): 5,3 mg/dl. Pada klien 2 $\mathrm{Ny}$. S setelah diberikan intervensi rebusan daun salam selama kurun waktu 7 (tujuh) hari dari hasil pemeriksaan didapatkan kasar asam urat pada hari ke 1 (pertama): $7 \mathrm{mg} / \mathrm{dl}$, pada hari ke 2 (dua): 6,9 mg/dl, pada hari ke 3 (tiga): 6,7 mg/dl, pada hari ke 4 (empat): $6,4 \mathrm{mg} / \mathrm{dl}$, pada hari ke 5 (lima): $6,0 \mathrm{mg} / \mathrm{dl}$, pada hari ke 6 (enam): $5,7 \mathrm{mg} / \mathrm{dl}$, dan pada hari ke 7 (tujuh): 5,2 mg/dl, sedangkan pada klien $3 \mathrm{Ny}$. L setelah diberikan intervensi rebusan daun salam selama kurun waktu 7 (tujuh) hari dari hasil pemeriksaan didapatkan yaitu kadar asam urat pada hari ke 1 (pertama): 6,8 mg/dl, pada hari ke 2 (dua): 6,6 mg/dl, pada hari ke 3 (tiga): $6,3 \mathrm{mg} / \mathrm{dl}$, pada hari ke 4 (empat): $6,3 \mathrm{mg} / \mathrm{dl}$, pada hari ke 5 (lima): 5,8 mg/dl, pada hari ke 6 (enam): $5,5 \mathrm{mg} / \mathrm{dl}$, dan pada hari ke 7 (tujuh): $5,0 \mathrm{mg} / \mathrm{dl}$. Hasil penelitian ini sesuai dengan penelitian sebelumnya yang dilakukan oleh Febriyanti, \& Mira, 2018 tentang pengaruh pemberian rebusan daun salam (syzygium polyanthum) terhadap kadar asam urat pada lansia juga didapatkan kadar asam urat sesudah diberikan intervensi selama 7 (tujuh) hari kadar asam urat yaitu $4,24 \mathrm{mg} / \mathrm{dl}$.

Terdapat perbedaan rata - rata kadar asam urat sebelum dan sesudah diberikan air rebusan daun salam yaitu pada klien 1 Ny. S selisih kadar asam urat sebelum diberikan terapi rebusan daun salam dan sesudah diberikan terapi rebusan daun salam selama 7 (tujuh) hari yaitu 1,2 $\mathrm{mg} / \mathrm{dL}$, pada klien 2 Ny. S selisih kadar asam urat sebelum diberikan terapi rebusan daun salam dan sesudah diberikan terapi rebusan daun salam selama 7 (tujuh) hari yaitu $1,8 \mathrm{mg} / \mathrm{dL}$, dan pada klien $3 \mathrm{Ny}$. L selisih kadar asam urat sebelum diberikan terapi rebusan daun salam dan sesudah diberikan terapi rebusan daun salam selama 7 (tujuh) hari yaitu $1,8 \mathrm{mg} / \mathrm{dL}$. Dari hasil rata-rata selisih kadar asam urat pada klien $1 \mathrm{Ny}$. $\mathrm{S}$, klien $2 \mathrm{Ny}$. S, dan klien $3 \mathrm{Ny}$. L, didapatkan penurunan kadar asam urat pada klien $1 \mathrm{Ny}$. S yaitu 1,2 mg/dL, sedangkan penurunan kadar asam urat paling banyak terjadi pada klien $2 \mathrm{Ny}$. $\mathrm{S}$ dan klien $3 \mathrm{Ny}$. L yaitu 1,8 $\mathrm{mg} / \mathrm{dL}$. Sehingga pada klien $1 \mathrm{Ny}$. $\mathrm{S}$ yang meminum air rebusan daun salam selama 7 (tujuh) hari belum efektif dalam penurunan kadar asam urat dikarenakan klien mengkonsumsi makanan yang mengandung tinggi purin, sedangkan pada klien 2 Ny. S dan klien 3 Ny. L yang meminum air rebusan daun salam selama 7 (tujuh) hari efektif dalam penurunan kadar asam urat dikarenakan klien menghindari makanan yang mengandung tinggi purin.

Faktor penyebab kadar asam urat didalam darah menjadi tinggi bisa dikarenakan faktor primer ( faktor bawaan), faktor sekunder ( faktor dari luar, misalnya diet yang salah, penyakit tertentu), dan juga faktor keduanya primer serta sekunder. Penyakit asam urat bisa berhubungan dengan pola makan, aktivitas, penyakit lain dan genetik. Penderita asam urat jika sering melakukan aktivitas yang berat makan penyakit asam 
urat akan sering kambuh (Kertia, 2009). Adapun makanan yang mengandung purin tinggi yaitu hati, jeroan, seafood, tape, alkohol serta makanan kaleng. Makanan yang mengandung purin sedang yaitu daging sapi, kerang-kerangan, kacang-kacangan, kembang kol, bayam, buncis, jamur, daun singkong, daun pepaya dan kangkung. Makanan yang mengandung purin ringan yaitu keju, susu, telur, sayuran, dan buahbuahan (Suiraoka, 2012).

Faktor penurunan kadar asam urat yaitu dengan mengurangi makanan yang kaya akan purin seperti jeroan, seafood, kacang-kacangan, bayam, kembang kol, alcohol, tape. Selain itu, bisa menggunakan pengobatan tradisional seperti rebusan daun salam untuk menurunkan kadar asam urat.

Daun salam (Syzygium polyantha) merupakan daun yang hampir selalu ada dalam masakan Indonesia. Daun ini banyak digunakan dalam kuliner Asia seperti Malaysia, Thailand dan Vietnam. Daun salam dapat digunakan dalam keadaan segar atau kering. Selain sebagai bumbu masakan, daun salam sebenarnya memiliki khasiat bagi kesehatan tubuh. Daun ini dipercaya dapat sebagai obat untuk menurunkan tekanan darah tinggi, meringankan nyeri akibat asam urat, menurunkan kadar kolesterol, dan mengobati diare (Savitri, 2016). Daun salam mengandung zat kimia berupa flavonoid, minyak atsiri, tanin, polifenol, vitamin B dan $C$ yang memiliki sifat diuretik sehingga memperbanyak produksi urin yang akan dikeluarkan dari dalam tubuh akibat sisa metabolisme dan dapat menurunkan kadar asam urat darah (Handadari, 2012; Febriyanti, \& Mira, 2018). Kandungan flavonoid diyakini berperan dalam menurunkan kadar asam urat dalam darah karena flavonoid dapat menghambat aksi dari enzim xanthine oxydase sehingga pembentukan asam urat terhambat (Suriana, 2014; Febriyanti, \& Mira, 2018).

\section{KESIMPULAN}

Terapi non farmakologi air rebusan daun salam terbukti dapat menurunkan kadar asam urat pada penderita asam urat, dengan dosis yang diberikan 200 cc atau 1 gelas, diminum sebanyak 2 kali setelah berbuka puasa dan saat sahur selama 7 hari. Didapatkan hasil kadar asam urat pada klien 1 sebelum diberikan terapi yaitu $6,5 \mathrm{mg} / \mathrm{dl}$ dan setelah diberikan terapi selama 7 (tujuh) hari yaitu 5,3 mg/dl, pada klien 2 kadar asam urat sebelum diberikan terapi yaitu $7 \mathrm{mg} / \mathrm{dl}$ dan setelah diberikan terapi selama 7 (tujuh) hari yaitu $5,2 \mathrm{mg} / \mathrm{dl}$, dan pada klien 3 kadar asam urat sebelum diberikan terapi yaitu $6,8 \mathrm{mg} / \mathrm{dl}$ dan setelah diberikan terapi selama 7 (tujuh) hari yaitu 5,0 mg/dl. Hal ini membuktikan bahwa air rebusan daun salam dapat dijadikan alternatif perawatan penyakit asam urat dengan murah, mudah, dan aman, serta efektif untuk menurunkan kadar asam urat. 


\section{DAFTAR PUSTAKA}

Eni, A., Ari, P. D., \& Riri, N. (2018). Faktor-faktor yang berhubungan dengan kejadian gout arthritis masyarakat Melayu. Jurnal JOM FKp, 5(2),683692.

Febriyanti, F \& Andhika, M. (2018). Pemberian Rebusan Daun Salam (Syzygium Polyanthum) Terhadap Kadar Asam Urat Pada Lansia. Menara Ilmu, 12(10).

Hasrul, R. M. (2017). Hubungan Tingkat Pengetahuan Perawat Terhadap Pelaksanaan Asuhan Keperawatan Spiritual Di Ruang Perawatan Rumah Sakit Nene Mallomo Kabupaten Sidenreng Rapang Tahun 2017. Jurnal Keperawatan Muhammadiyah, 2, 1.

Kementerian Kesehatan Republik Indonesia. (2018). Riset Kesehatan Dasar Pravelensi Penyakit Sendi Berdasarkan Diagnosis. Diakses dari: http://kesmas.kemkes.go.id/assets/upload/dir_519d41d8cd98f00/fil es/Hasil-riskesdas-2018_1274.pdf

Kertia, N. (2009). Asam Urat. Yogyakarta: B First.

Kumar, B., \& Lenert, P. (2016). Gout and African American reducing dispaties. Amerika: Clevaland Clinic Jurnl of Medicine.

Ningtiyas, I. F., \& Ricky, M. R. (2016). Efektivitas Ekstrak Daun Salam untuk Menurunkan Kadar Asam Urat pada Penderita Artritis Gout. Fakultas Kedokteran Universitas Lampung.

Roza, M., \& Putri, D., (2016). Pengaruh Pemberian Air Rebusan Daun Salam Terhadap Penurunan Kadar Asam Urat Pasien Arthritis Gout. Jurnal Kesehatan Saintika Meditory, 2(1), 62-70.

Sari, Y. A., \& Syamsiyah, N. (2017). Berdamai Dengan Asam Urat. Jakarta: Tim Bumi Medika.

Savitri, A. (2016). Basmi penyakit dengan TOGA (Tanaman Obat Keluarga). Depok: Bibit Publisher.

Setianingrum, P. D., Istika, D. K., \& Dwi, K. R. (2019). Pemberian air rebusan daun salam (syzygium polyanthum) terhadap penurunan kadar asam urat pada penderita asam urat di Dusun Kadisoro Desa Gilingharjo Kecamatan Pandak Kabupaten Bantul DIY. Jurnal Kesehatan Edisi Khusus No.1, 12-23.

Suiraoka, I.P. (2012). Penyakit Degeneratif. Yogyakarta: nuMed.

Utomo, F. (2014). Pengaruh Pemberian Air Rebusan Daun Salam Terhadap Penurunan Kadar Asam Urat Pada Lansia Di Tegalsari Salatiga. Program Studi Ilmu Keperawatan. Universitas Satyawicana Salatiga.

World Health Organization. (2017). WHO methods and data sources global burden of diasese estimates 2000-2015.

Wiraputra, I. B. M. A. (2017). Gouth Arthritis. Pengalaman Belajar Lapangan (PBL) Fakultas Kedokteran Universitas Udayana. 